\title{
The Primary School Movement in the South Slav Lands of the Habsburg Monarchy in the Era of Dualism. Ideal and Reality
}

\author{
Robin Okey \\ University of Warwick
}

The roots of this paper go back to the author's early days in Sarajevo researching Austro-Hungariancultural policy in Bosnia. As a naïve young man from the cold North I was delighted by the idealism of nineteenth-century Balkan pedagogy, the language of the noble mission of the primary school to guide a suffering people towards the light of national progress. But even a naivve young man soon saw that the ideal did not fully correspond to the reality. It took longer to realize that the contrast between affecting aspiration and practical constraints is the tale of primary education in almost all modernizing contexts. Common to all such situations was the struggle to create a new, autonomous and respected branch of the teaching profession in an era of rapid change and increasing social competition. More distinctively Balkanwere the problems of implementing ideas drawn in part from central and western Europe in less developed milieux. The 'people's school' proved a challenging concept in lands where the people were often divided confessionally and ethnically, subject to foreign rule and too poor to sustain some of its underpinnings. Yet Balkan exceptionalism in these respects can be exaggerated and the use west European primary school teachers made of philosophical notions among the elite has parallels with the transmission of ideas between different parts of Europe. The present papermakes no claim to novelty, though it links the experience of various regions, and presents the primary school experience in terms of the teachers' movement,a little more than is customary. The concentration ismainly on Croatia-Slavonia and Bosnia of the late Habsburg Monarchy's south Slav lands, with archival material confined largely to Bosnia and illustrations based on some of the extensive pedagogical literature of the time.

The primary school has only a modest part in mainstream Balkan historiography. A fine institution, the specialist 'school museums' founded in the 1890s on Czech lines in Zagreb, Belgrade and Ljubljana, has perhaps unwittingly contributed to this marginalization and the relative absence of overarching perspectives, even in the Yugoslav period. An exception was the cooperative Zbornik za historiju školstva i prosvjete, published in Zagreb, then Ljubljana, from 1964 to 1990, whose editor, DragutinFranković, was also responsible for two important works on Croatian education. ${ }^{1}$ The Vojvodina-orientated Pedagoška stvarnost (Novi Sad) published annually from 1955 is the longest standing historical periodical in the field. In Bosnia work has had a relatively narrow focus on establishing a record of statistical and curriculum development, maintenance and regulation. ${ }^{2}$ Wider attention has been accorded primary education chiefly when it most directly involved national issues, as in questions of the language of instruction or in critiques of Habsburg policy, or Serb-Croat confrontation. ${ }^{3}$ By the same token, the historiography of secondary education is more extensive because that education contributed more obviously to the emerging intelligentsias which Balkan lands needed in the process of 'modernisation'. In fact,

\footnotetext{
${ }^{1}$ Franković 1958; Ibid. 1971.

2 Works covering primary education include Bogićević 1965; Papić 1972; Curić 1983; Kasumović 1999.

${ }^{3}$ For example, Slijepčević 1929; Kirilović 1935; Perić 1974; Krestić 1997.
} 
as advocates of the 'people's school' were at pains to point out, their movement had a crucial contribution to make to this process. The difficulties they faced in getting their claim not only verbally acknowledged, but acted upon, illustrate the uneven balance of forces within Balkan society. Besides the religious, ethnic and political obstacles mentioned above, a fault-line between masses and native elites also dogged teachers' attempts to implement their ideals in a framework shaped by stronger power players. The mixed fortunes of the 'popular school' vision which took shape in the 1860s and 1870s offer an engrossing perspective on Balkan social and political history.

\section{The rise and ideas of the movement for the 'people's school'}

Before the nineteenth century outside a few larger towns the large majority of children had no access to organized primary education. Bosnian koranic schools (mektebs) were widely attended but offered only religious knowledge and did not teach pupils to read their mother tongue. Legislation in Austria (1774) and Hungary (1777) laid down the principle of general, structured schooling. The impact was severely limited. Literacy in Slovene-speaking lands is estimated at less than ten per cent at the end of the eighteenth century, though real progress was made among the Monarchy's Serbs at this time. ${ }^{4}$ Civil Croatia had only some hundred schools in the late 1830s, while in the Military Frontier, with its own educational traditions, there were more than six hundred with twenty six thousand pupils, many of them taught in German. Some acceleration can be seen preparing the way for the second half of the century. Dalmatia had 32 primary schools in 1830 and 175 in 1847, Civil Croatia 229 in 1851 with sixteen thousand pupils, a third of them girls. But this was still only 29.4 per cent of the children between six and twelve years old. ${ }^{5}$ Outside urban centres schooling was still almost entirely traditional in content and methods, with teachers often treated as little more than servants of the parish priest.

\footnotetext{
${ }^{4}$ Stih / Simoniti /Vodopivec 2008, 219. Slovenia will not be further treated in this chapter, as outside the Balkan sphere, but this low figure is indicative.

${ }^{5}$ Šidak 1981, 189-202 (192-93).
}

The developments that followed built on the positive approach the Enlightenment and Josephinism had already taken to change and which neo-absolutism endorsed in its goal of state efficiency. Yet it was now bound up with a powerful liberal-national drive which challenged all old hegemonies in a society felt to be in flux. It is tempting from today's perspective to relativise what was at stake to partial adjustments in class society enabling a rising but still small bourgeoisie to improve its position alongside traditional elites. To contemporaries it seemed a matter of volcanic shifts breaking up ancient power structures, and opening up prospects of a new order, where former subjects became citizens in polities bound not by force but by fraternity. What more natural than that teachers should see a heady role for themselves as front-line workers in this great enterprise? The task of the 'people's school' was to turn a mechanical process of dragooning subalterns into pliable instruments of their masters into the awakening of young minds to the undreamt of potential of modern progress. On the shoulders of pedagogical pioneers like Comenius and Pestalozzi had arisen a pleaide of internationally famous scholars, men like Johann Herbart, Friedrich Diesterweg and Friedrich Dittes, writing in the major European language most familiar to Habsburg south Slavs: the term 'people's school' (pučka or narodnaškola) was itself a translation of the German 'Volksschule. These man stood for an avowedly scientific approach to pedagogy, endowing it with all the credentials of modernity. Their names and those of other western scholars dot the pages of south Slav educational periodicals, reflecting the eagerness with which able men on the periphery sought to assimilate the insights of the European cultural heartland.

The result was a period of almost constant discussion on school organization and programmes, with landmark legislation in the post-absolutist era in Banal Croatia (1874), the Serb Orthodox Patriarchate of Sremski Karlovci $(1868,1872)$ and the Military Frontier (shortly to be absorbed in Banal Croatia) in 1871. Against this background the time was ripe for new groups to claim a social role. As yet, Bosnia-Herzegovina remained outside this framework. Its school law of 1869 was conceived in a quite different environment. It was in its own way a response to 
the challenge of modernization, to the impact of new ideas from a European centre to a less developed periphery. But Bosnia found itself on a double, if not treble periphery, of the overwhelmingly Christian Europe of which it was geographically part and of the mainly Muslim Ottoman empire, itself increasingly dependent on the European great powers. The 1869 school law was designed to relieve pressure from the latter by showing Ottoman capacity for reform. It sought to unite the multicultural realm around a project of 'Ottomanisation', shifting the ostensible focus of loyalty from Islam to the common state under the impartial administration of modernizing bureaucrats. Consequently, bearing in mind the limited resources of the Ottoman state, it was essentially an elite project. In Bosnia it introduced the ruždija, a kind of secondary school where future officials could receive the rudiments of secular education through Ottoman Turkish. It had virtually no impact on primary and koranic education. The incoming Austro-Hungarian administration found in Bosnia in 1879 some five hundred mektebs and a mere 110 Christian confessional schools teaching about 5600 pupils.

Meanwhile, in the Monarchy three interlocking and reinforcing factors in the field of primary education led to the emergence of a teachers' movement which, if greatly varied within itself, reflected a set of interests and attitudes which defined it vis-á-others: the creation of a network of full-fledged teacher training colleges, starting with Zagreb in 1847; the rapid growth of a teachers' press; and the liberal principle of association. Teachers' training had been part of the Theresan and Josephinist reforms. What happened in the second half of the nineteenth century was the expansion of training courses from a few months or even weeks to two, three and finally four years. Thus the Serb men's college at GornjiKarlovac opened as a two-year course in 1875 , which became three-year in 1878 and was fouryear when the college relocated in 1895 . Time grew to accommodate the pedagogical theory to be mastered and the steadily increasing number of subjects which the primary school was supposed to teach, like history and geography, music, basics of natural science, agriculture/housework, gymnastics and hygiene. In turn the need to explain the complex methodologies and constantly changing syllabuses stimulated a new genre of journalism, the pedagogical periodical. Seven were published by the Serb minority in Croatia-Slavonia alone in the Dualist period. Zora (Zadar) presented itself to Dalmatian teachers specifically as a forum to discuss the 1879 Dalmatian syllabus, answering a need it said had been felt ever since the syllabus appeared. ${ }^{6} \mathrm{Re}$ gular teachers' meetings mandated by school legislation at county or diocesan level provided a further forum. Finally, in the spirit of the new age independent association offered a framework for action. It was organized Zagreb teachers' draft of a more liberal school law in 1865 , followed by well-attended general assemblies of Croatian teachers in 1871 and 1874, which helped to secure the legislative success of 1874 . Institutionally, the Croatian Pedagogical-Literary Convention ( $\mathrm{Hr}$ vatski Pedagoško-književni zbor: HPKZ) founded in 1871 provided intellectual and publicistic support. The grouping of local associations into the League of Croatian Teacher Societies (Savez hrvatskih učiteljskih društava, 1885) showed how a sustained organized movement had come into being, for its function was to defend the gains of 1874 against attack.

At the core of this activity was the belief expressed by the movement's leading journal, Napre$d a k$, in its second ever number in 1859: 'A new time has given birth to new and greater needs.' Teachers saw themselves as in tune with this new time, which the school was called upon to serve. This gave them a sense of importance and entitlement. After all, the state of popular schooling was the measure of a state's strength and power, as Stjepan Basariček declared; without its development a progressive state was unthinkable. ${ }^{8}$ It followed that in the broadest sense the movement was progressive. It embraced an interest in the natural world and the new knowledge and insights of the age. Napredak's opening number had an article on physical well-being, including the correct position of the eyes in reading. ${ }^{9} \mathrm{Su}-$ bscribers were treated to such speculations as to when men first appeared on the earth and informed that the water vapour regularly given off by plants would cover the whole earth with

\footnotetext{
${ }^{6}$ Zora. Učionski časopis, 1, no. 1 (1884), 1-2; no. 3, 17-18.

${ }^{7}$ Napredak: časopis za pedagogiju, 1 (1859), no. 3, 33.

${ }^{8}$ Ibid., 10 (1869), 17-19; 15 (1874), 114

${ }^{9}$ Ibid. 1 (1859), 4-9: I. Macan, 'Skerb o tjelesnom blagostanju školske mladeži?
} 
four feet of water. ${ }^{10}$ Other journals followed suit. The Hungarian Serb Učitelj declared the nineteenth century to be the century of natural science; its successor Nova škola highlighted a modern tendency towards the natural and physical sciences which worked for prosperity and education. ${ }^{11}$ Further progressive opinions expressed in Napredak involved criticism of corporal punishment, objections to student halls of residence as savouring of the unfree spirit of the seminary, and most constantly, a sympathy with women's causes which remained a staple of progressive pedagogy. The right of married women to teach was one of the most keenly discussed topics for decades. Most central, however, was the development of modern curricula in well-equipped schools, as far as possible free from clerical and government tutelage, though the right of state supervision (Aufsicht, nadzor) was unquestioned in the well-ordered secular state which was posited by the central European liberalism to which Croat progressives aspired.

All this drew teachers willy-nilly into the sphere of religion. Operating in strongly Catholic Croatia and aiming at broader social support, Napredak, took an emollient line, which was no doubt not merely tactical, though it was launched when the neo-absolutism still prevailed. Education was regularly seen in a religious moral context. Only religion could be a firm foundation for a good building, claimed an early number; people like Rousseau had gone astray. ${ }^{12} \mathrm{Mo}-$ dern themes were often given a religious gloss. The 'struggle for life' was a matter of using the skills God had given: it was because the ancient Greeks and Romans did not know the laws governing nature that they remained superstitious pagans worshipping natural forces, rather than the creator God these laws obeyed. ${ }^{13}$ But religion was advocated in conjunction with tolerance, and the religion children needed was not one of 'incomprehensible dogmas' but of God's eternal love and the beauty of his creation. ${ }^{14}$ The religious establishment did not mistake the challenge to

\footnotetext{
${ }^{10}$ Ibid., 10 (1869), 8-11, 47.

${ }^{11}$ Učitelj, 1 (1873), 53; Nova škola. Nezavisni učiteljski list, 3 (1877), 22

${ }^{12}$ Napredak, 1 (1859), 17.

${ }^{13} \mathrm{Ibid}, 1$ (1859), 49-50; 10 (1869), 24, from an article entitled 'Važnost priznanja prirode'.

${ }^{14}$ Ibid., 10 (1869), 161-6: 'Nabožno-ćudoredni uzgoj mladeži’.
}

their authority which teacher self-assertion entailed. Against the Archbishop of Zagreb's stress of obedience, Napredak invoked the Bible to the effect that the only unconditional obedience was to God, not man. ${ }^{15}$ Croatian teachers might be loyal to religion but not to the hegemony of priests whose relations with teachers at local level were often poor. The future director of primary education in occupied Bosnia, the young Ljuboje Dlustuš, commented dismissively on the clergy's supervisory role in education in 1873 and called for a new school law and proper system of control. ${ }^{16}$ Another prominent educationalist, Jozef Klobučar, noted that man indeed did not live by bread alone but he could not live without it. ${ }^{17}$ The most eloquent statement of confidence in teachers' specific mission came from a man criticised for 'opportunism' in the communist period, Stjepan Basariček. In his most outspoken statement Basariček wrote in 1871 that for all the role played by commune, state and church, these should serve the school, not the school them. 'Only a free school can educate a free nation'. People's school teachers should not seek recognition as state officials because the state's goal was to train men for the use of the state, thereby making man a means. As Rousseau had said, man by nature was a whole for himself. Each man's goal was the same as all humanity's. ${ }^{18}$ This was the pure milk of liberal humanism.

The most influential expression of progressive teachers' concerns came, however, in the Bečke pedagoške slike in which the leading organizer Ivan Filipović described his impressions of the nineteenth annual conference of German teachers held in Vienna in 1869. The nationalminded Filipović (1823-1895), no friend of Germans, was inspired by the strength of the German movement displayed at the Conference to urge his compatriots to appreciate and emulate a more advanced nation's experience. He was particularly struck by the speeches of the Saxon educationalist and Vienna professor Friedrich Dittes, a convinced democrat and advocate of the

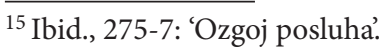

${ }^{16}$ Ibid., 14 (1873), 52-4: 'Mane našega narodnoga školstva i kako bi jih valjalo ispraviti', 153, 163.

${ }^{17}$ Ibid., 21 (1880), 4.

${ }^{18}$ Ibid., 12 (1871/2), 65-6, 73-5. Basariček was polemicising against a clerical journal which had called for teachers to seek the status of officials.
} 
principle of the free school in a free state. It was Dittes's discussion of the teaching of religion and of the woman question on which he dwelt longest. Filipović was convinced by Dittes's line that religion should be taught but by the lay teacher not a priest and, impressed by the spectacle of women speakers, he drew the logical conclusion that women should also be politically enfranchised. The whole episode shows the international nature of the schools movement mediated to the south Slav world and also the psychological framework of Balkan reception of outside ideas. Filipović revealed the attraction which radical European ideas could hold for Balkan intellectuals, but also took from Dittes an awareness of the need for compromise. Freedom was the key word of liberal optimism in 1860s Europe. It reflected a widespread confidence that the free individu$\mathrm{al}$, the free nation and a free humanity were all part of a seamless web which progress was bringing into being. This European liberalism, like Filipovićs, had a strong national dimension. The optimism of the age made him a strong believer in Croat-Serb brotherhood and interconfessional education, which he saw as the means of cementing Yugoslav unity. ${ }^{19}$ Remarkable in hindsight is how much of the progressive programme was won in the 1874 Croatian school law. Passed in the optimistic early days of the regime of the poet-patriot Ban Ivan Mažuranić, it provided for public, interconfessional schools, limited clerical supervision, and met teachers' wishes on teacher training, pensions and equal pay for women teachers. This was the high-point of the Croatian teachers' movement and a watershed in Habsburg south Slav education as a whole.

This Croatian development fits into a variegated picture. Within barely a generation remarkably similar patterns of teacher training and publication, district and provincial associations, and curriculum debate spread to the furthest corners of the Habsburg south Slav lands, a process finalized when the launching in 1906 of the journal Hrvatska prosvjeta put the coping stone on institutionalization of the teacher movement among Istrian Croats. ${ }^{20}$ Yet the ideological flavor could take quite different forms. The Serb perio-

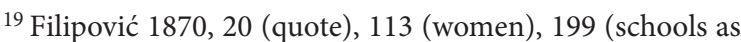
unifying factor in 'divided nation').

20 Šetić 2010.
}

dicals of the 1870s, Ucitelj and Nova škola, had a more radical edge than the liberal Napredak. Both mentioned Darwin and were more pointed about the implications of contemporary theories for human origins and religious beliefs. In this perspective religion was already a thing of the past, which stressed belief rather than investigation. For Ucitelj the idea of God, the father of all nations, had been important in the childhood of civilization but had ossified into dogma and reflected essentially its child-like origins. Well has it been called the first Serb socialist periodical. ${ }^{21}$ But the difficult circumstances of the SremskiKarlovci patriarchate soon brought its closure. By contrast Dalmatia's Zora piously abjured 'progressive' ideas. Its solemn declarations of belief in women's rights compared amusingly with the horror picture it then painted of the unmarried American girl. In this case, however, the programmatic intentions may be given some weight by twenty-first century readers. Actual clerical papers paid no lip service to women's rights at all. ${ }^{22}$ In fact, Zora shared the teacher movement's sense of professional interests vis-à-vis religious control and a wish to build up the school, even in the rural hinterland. ${ }^{23}$

Ironically, in view of its Ottoman background and the absolutist nature of Habsburg rule, it was occupied Bosnia after 1878 that offers closest parallels, both positive and negative, with Croatian experience. The chief links lay in the interconfessional nature of most Bosnian schooling, and to a degree in personnel. The abortive school law of 1879 , drafted by one of the many Croat officials of the early Landesregierung, Milutin Kukuljević, posited communal schools on interconfessional lines quite in the spirit of the Croatian liberalism of the 1870s. It was condemned for this by both Austrian and Hungarian culture ministers and never promulgated. ${ }^{24}$ When the long-serving Benjamin Kállay (1882-1903) finally regularized the occupation's school system he endorsed, however, the same principle. He had, of course,

\footnotetext{
${ }^{21}$ Učitelj, 1 (1873), 116-119; ibid., 2 (1874), 81-7. See also Nova škola, 3 (1877), 97-101. For Učitelj and socialism, see D. Kirilović, Učitelj. Prvi srpski socialistički časopis, Zbornik Matice Srpske za književnost i jezik, 1 (1953).

${ }^{22}$ Zora, 2 (1885), no. 12: 'Žena i njezino pitanje'. For an unsympathetic clerical take on modern women, see Hrvatski učitelj, 3 (1879), 305-11.

${ }^{23}$ See below, p. 155.

${ }^{24}$ See Okey 2007, 49-50.
} 
his own political motivations. He wished to weaken the existing nationally-minded Serb confessional schools, and he believed only a non-confessional system could win Muslims for a process of Europeanisation. Kállay was an enemy of south Slav nationalism but he was also a man of modern cultural outlook who aimed at good (if few) schools, very many of whose teachers, particularly in the occupation's earlier years, came from Croatia, drawn by better pay than in their homeland. Such people were flying to Bosnia, it was alleged in the Croatian Diet in $1894 .{ }^{25}$ These included Ljuboje Dlustuš, who supervised Bosnian primary education for thirty years. Dlustuš had been a contributor to Napredak. A man of great energy, he edited the provincial pedagogical journal Školski vjesnik from 1894 till his retirement in 1909. With regularly a thousand closely printed pages it maintained a high standard of wide-ranging material on pedagogical methodology, history and current reportage, as well as reviews and articles on general historical, literary, philosophical and psychological themes, all breathing the earnestness of the age and genre. Školski vjesnik was an official publication, and aspects of the people's school movement like teachers' assemblies did not take place in absolutist Bosnia till after Kállay's death- the first such all-Bosnian conference was in 1906. Nonetheless, evidence that much of the aspiration and idealism of that movement penetrated Bosnia lies in contributions to Školski vjesnik from $\mathrm{Mu}$ slim teachers like H. Fazlagić and Hamid $\mathrm{Mu}-$ lić showing these qualities. The pioneer of the modern Bosniak novel, Edhem Mulabdić, was another teacher, whose most famous novel featuring a young Muslim who learns Latin letters secretly from an Austrian soldier was at this point autobiographical. ${ }^{26}$ Mulabdićs acceptance in the Sarajevo teacher training college though he had no formal western schooling shows how anxious the regime was to encourage Muslim participation.

Dlustuš wrote once that Bosnian pupils should develop the consciousness that they spoke the same language and belonged to the same nation and homeland. He must have appreciated Mulićs words: 'Our national spirit requires

\footnotetext{
${ }^{25}$ Cuvaj 1913, 234.

${ }^{26}$ Mulabdić 1898.
}

that our education (uzgoj) is national; let us then educate our youth from their first steps till the conclusion of their scholarly or apprenticeship in brotherly love and tolerance. ${ }^{27}$ Both statements could be understood in the spirit of unity that was so important to Ivan Filipović as the goal of the people's school the expression, as he saw it, of the national liberalism of a progressive age. In fact, this vision was not achieved. Both its liberal and its national themes posed problems, and external political and internal social factors compounded them.

\section{The people's school: religious and ethno-national problems}

In effectively challenging the Catholic Church the teachers' movement was taking on an opponent even stronger than it thought, and on an issue close to the Church's heart. Due to the Church's self-image was the role it claimed as the cradle of European culture and the source of succour and hope to the faithful masses ignored by the worldly and powerful. Cardinal Haulik, till 1869 long-standing archbishop of Zagreb, had devoted much attention to primary schooling, though in terms which showed both its primary function to serve the Catholic faith and the humble role suitable clerks or organists might play as teachers. ${ }^{28}$ The assumption of the liberal age was that the Church's power, while still great, belonged essentially to the past and that time was on the side of modern educators. In the second half of the nineteenth century this proved largely mistaken. A Catholic revival was to throw off the shackles, as its leaders saw it, of the passive subservience to government represented in Austria by Josephinism and take advantage of liberal weapons of press and association to project its own message against its enemies. Even liberal Catholics like Bishop Strossmayer had no intention of yielding the Church's role in a free national life to other forces; he did not give a horse-bean for western educational theories, he told

\footnotetext{
${ }^{27}$ Dlustuš 1909, 7; H. Mulić, 'Narodno prosvjećivanje', in Mustafić 2008, 293.

${ }^{28}$ Deželić 1929, 24-8, 47-52. Haulik became bishop in 1837 , before the see became an archbishobric in 1850 .
} 
Prince Nikola of Montenegro. ${ }^{29}$ But in a world of Bismarck's Kulturkampf, the loss of the Pope's temporal power and mounting anti-clericalism, the Church was moving away from Strossmayer. The Jesuit-educated Archbishop Stadler in Sarajevo (1881-1918) was its new face. The Serb Orthodox Church and the Bosnian ulema were less imposing foes, but their power to thwart the people's non-confessional school rested on a potent nexus between faith and ethnicity, implicit among Bosnian Muslims, but explicitly national among Serbs.

Already Filipović had had to recant having written that no religion was better than another in order to obtain a teaching post in Zagreb in 1863. Privately, he believed the Church used Croatian nationality to maintain its 'empire of stupidity and darkness' against new ideas from outside. One clerical charge in the debate on the 1874 school law was that it amounted to 'a denial of positive religion, and that is materialism, nihilism. ${ }^{30}$ In context this was code for the rationalisation of religion in the work of Filipovićs model, Dittes. Dittes, as his defenders strove to emphasize, was not an unbeliever, but he and his own hero Diesterweg, were Protestants. Diesterweg had said that modern man faced a choice between authority and freedom, between Catholicism and Protestantism. Educational reformers in pious, conservative Croatia were being very bold in their choice of models. Napredak was to write that the battle to repeal the 1874 school law began the day it was passed. A rival, anti-liberal school journal existed from 1868. It did not help that public opinion on the new school system largely sided with its clerical and other critics. At issue were alleged over-elaborate syllabuses and methodology and a general sense that the school had been over-sold to an increasingly skeptical public. ${ }^{31}$ An 1879 pamphlet on the 'anti-school reaction', very likely by Filipović, shows impressive awareness of the problems facing a small, developing society in a time of intellectual ferment. It argued that gains in understanding of the laws of nature, in an age of specialization, could distract from ethical factors and hinder the achievement of the right balance between

\footnotetext{
${ }^{29}$ Zapisi. Glasnik Cetinjskog istorijskog društva, 13 (1935), 30 (2 March 1879).

${ }^{30}$ Franković 1958, 163.

${ }^{31}$ See the article series by Klobučar 1880 .
}

realism and idealism. Small societies like Croatia, with a derivative culture, lacked the expertise to handle the gap between these two tendencies and the resultant materialism and money values, which were not yet rooted but incipient. Hence materialists could deny teachers' claims (borne out in more advanced lands) that peasants and workers cared for civilization and theologians could decry new ideas. Humanity's advances always brought reaction, Filipović concluded, but compromises in the face of such forces had to be made. ${ }^{32}$ One of these appears to have been the decision to make Herbartism the theoretical basis of Basariček's path-breaking Croatian-language work Pedagogija (1880), instead of the more radical ideas of Dittes and Diesterweg who had been the movement's chief models. ${ }^{33}$ Conservative pressures continued, however, in line with tendencies throughout the Monarchy in the 1880s. A new school law in 1888 allowed communes to relax the six year term of study and made forty rather than thirty years' service necessary for a full pension. The decision of the HPKZ leadership at the Church's behest to apologize for the publication of a translation of Rousseau's visionary work Emile disillusioned Filipović. In face of its unwillingness to support him against the government he resigned from it in 1892 and died three years after. The radical spirit of the Croatian teachers' movement died with him. Significantly, he retained to the end his faith in Serb-Croat solidarity. Khuen-Héderváry, Croatian ban from 1883 to 1903 , succeeded in dividing others through concessions to Croatian Serbs in matters like the use of Cyrillic and minor concessions to Serb confessional schools in the 1888 school law. The souring of the national element in the people's school movement, due also to competition over Bosnia, was a symptom of decline.

Clerical forces were also a powerful factor in Bosnia. The language of tolerance central to ideas of unity ran up against the Sarajevo Archbishop Stadler's charge of 'indifferentism' on matters of faith; Muslims objected to textbook presentations of Mohammed; individual Catholic teachers were accused of trying to convert Orthodox pupils to the Uniate or Greek Catholic Church. The

\footnotetext{
${ }^{32}$ Filipović 1879.

${ }^{33}$ Franković 1971, 24.
} 
biggest problem was the aversion of the great majority of Muslims to attending the communal schools. Kállay resorted to a special institution combining Oriental and European subjects and called ruždija's to imply continuity with the Ottoman past. In 1893, in towns with such schools, nearly ninety per cent of Muslim pupils having any form of western education at all were in ruždija's, and a mere forty three in conventional communal schools. ${ }^{34} \mathrm{~A}$ movement to introduce the so-called mekteb iptidaije (reformed mekteb) already established in Turkey offered a possible avenue to use of the mother tongue, as in koranic instruction in Turkey. Reformed mektebs taught the traditional material but along modern lines with organised syllabuses, text books and fixed three-year terms. Early experiments did teach in Bosnian but at the wish of the Austrian-created Medžlis-el-Ulema this was dropped, in return for an agreement that reform mekteb graduates would proceed to a communal school. This limited their impact since they offer access to a modicum of mother tongue literacy in the Muslim countryside - where there were no communal schools to go to. Moreover, reform mektebs declined as a government-linked institution during the Muslim movement for cultural autonomy (1899 to 1909$).{ }^{35}$ When the autonomy was won some Medžlis members still opposed the teaching of Bosnian in reform mektebs, which was finally accepted only with the use of a modified Arabic alphabet. Just five per cent of Muslim males and a negligible number of women were literate in their mother tongue by 1914 . The people's school experience had barely touched the Bosnian $\mathrm{Mu}-$ slim community.

Muslim solidarity had an ethnic as well as a religious aspect, though not yet explicitly national in the modern Bosniak sense. Among Serb Orthodox the nexus between religion and nationality was clear. This greatly complicated the issue of interconfessional schooling. Problems took an acute form in Croatia-Slavonia. Attempts to regulate the status and standards of schools in the pre-constitutional era, had often faltered in face of the confusing diversity of existing provision, whereby schools were linked in various ways

\footnotetext{
${ }^{34}$ Arhiv Bosne i Hercegovine (ABiH), Zajedničko ministarstvo financija (ZMF), BH 13791/1893: ZV (Zemaljska vlada) to ZMF, 21 November 1893.

${ }^{35}$ On Muslim education, see Okey 2007, 99-104.
}

to communal, confessional or (in the Military Frontier) military authorities, or to shorter-lived individual initiative. The effect of the 1871 Regulations on Instruction in the Elementary Schools in the Military Frontier and of the 1874 Croatian school law was to weaken the position of Serb Orthodox confessional schools. The law recognized the category of confessional schools. But many Serb schools could not meet the standards required, or else schools deemed confessional by homogenous Serb populations but maintained wholly or in part by the local commune were registered as communal. The result was a sharp fall in that Serb confessional school numbers except in the richer Karlovci diocese. ${ }^{36}$

The complaints of the Serb Orthodox Church about this development were perfectly natural. Đorđe Natošević, the confessional school inspector for Croatia-Slavonia under the Karlovci Patriarchate's cultural autonomy, expressed dignified dismay at the compulsory extension of non-confessional schools beyond areas of mixed population to purely Serb ones. The 1871 and 1874 legislation also disregarded the provisions the Serb authorities had themselves made for reform of their schools by virtue of their recognized autonomy. More dubious were the echoing of religious objections to 'communalization' of schools from Serb lay leaders who were fighting bitterly against their own clergy. There is an element of hypocrisy in the 1875 memorandum of protest of the secular-minded lay-dominated Serb National Congress, pleading the necessity of several hours a week for the teaching of church singing and an equivalent time over several years for mastery of the Old Slav language of Orthodox services - which could only be imparted by the teacher in a Serb confessional school. ${ }^{37}$ When these men stressed the historic ties between Serb nationality and religion they were sincerely reflecting a reality, but their interest was wholly in developing the national side of the relationship. The confessional school for these members of Svetozar Miletićs National Liberal Party was the mirror image of Filipovićs people's school, only it should be a Serb people's school.

Vasilije Krestić in his 1997 work on the history of Croatian Serbs repeats and internalizes

\footnotetext{
${ }^{36}$ Krestić 1997, 225-56.

${ }^{37}$ Ibid., 247-48.
} 
the arguments of his nineteenth-century protagonists: 'They knew very well that the communalization of Serbian schools was only a stratagem in the attempt to denationalize and Croatize Serbian children and all the Serbs in Croatia. ${ }^{38}$ Krestićs analysis is anachronistic in imputing motives to nineteenth-century actors based on perspectives and perceptions not fully open to them. He does point to genuine problems. The communalization of Serb schools cannot just be explained away by their poverty and weaknesses (which Krestić acknowledges) as the result of a rationalizing process. There was an element of 'smislenost' in Nova škola's term. ${ }^{39}$ Filipovićs reference to the need for non-confessional schools in the interest of 'national unity' implies a willingness to see confessional schools disappear. But to equate this with 'denationalisation' and Croatisation and to include Filipović in the indictment is to ignore Filipovićs Yugoslavism. Like nineteenth-century thinking on nationalism in general Yugoslavism assumed under Herderian influence that language, not religion, was the basis of nationality, so that Krestićs rigid Croat-Serb polarity is misplaced. It reflects later disillusionments. Men like Filipović were quite aware of a distinct Serb and Croat nationhood, and of Serbdom's religious dimension, but thought this negotiable, in the same way, no doubt, as modern Scots can be Scottish and British. The religious dimension was recognised in Croatian inter-confessional schools in the provision for religious instruction by priests of each pupil's faith. Cyrillic was taught to all - Croat nationalists objected to its introduction already in the second year in 1887 - and the 1874 act included a clause saying any reference to the Croatian language of instruction implied the identical Serbian language in Serb schools. This was not, of course, the most tactful way to put it. The Yugoslavism of men like Filipović was Croat-tinged, but then they were living in a majority Croat country with a national name and history. For Croats to have accepted formulas preferred by Serbs of a binational Croatia would, alongside a monolithic Serbia, have meant internalizing a rather uncomfortable view of their marginality, all the more so as it was, as was well known, the view of them held

\footnotetext{
${ }^{38}$ Ibid., 225.

${ }^{39}$ Nova škola, 4 (1878), 145-51: 'Sudbina naših škola'.
}

by many Serbs. No doubt Croats could be uneasy at the thought of Serb schools putting over such hegemonistic notions to their pupils, just as Serbs could resent the encroachment of a Zagreb administration and anti-Serb prejudices. But the situation was not fully polarized. Some radical Serb teachers felt they were being used as tools in the anti-communalization battle by politicians of the 'so-called national liberal party. ${ }^{40}$ Fighting the patriotic fight meant for them sacrificing the chance of better pay and conditions as a communal teacher. The owner/editor of the proto-socialist Učitelj, Mita Neštrović himself believed confessional schools should not be developed at the cost of communal schools, which were better. ${ }^{41}$ The situation was fluid and the camps Krestic presents in battle were only in process of being created, in part through the polarising ideologies he reproduces in his book. Plainly, there was a genuine problem, and there were national moderates and intransigents on both sides. The tragedy is that people on both sides have stressed only the threat to their own sense of identity and refused to recognize the good will and the dilemma in the other camp.

These issues deserve more thorough treatment than given here. If an outsider may venture an observation, it would be that discussion of Balkan themes can be burdened with notions of a negative 'Balkanism', internalized even by Balkan people themselves, in the sense of a zone held back by atavistic backwardness from the course of social evolution taken in more 'advanced' lands. True, the overlap of religion and nationality has had particularly fateful consequences in the Balkans. But it is not unique to them. Contemporary historians now see a much greater role for religion in the nineteenth-century European world of Kulturkampf than a generation ago. In the British Isles Catholics and Protestants go to separate schools to this day, and the distinction between British and Irish national identities in Northen Ireland rests basically on religion. The belief, however, that there is a norm achieved elsewhere which Balkan countries have failed to reach encourages partisans to seek culprits for the failure. One side sees itself as embodying the rational modern norm and accuses the other of

\footnotetext{
${ }^{40}$ Ibid., 1 (1875), 10 October; 104.

${ }^{41}$ Školski list, 37 (1907), 178-9.
} 
sins of atavism and nationalism. This is what has happened in the case of Vasilije Krestić.

By comparison with those in Croatia-Slavonia Serb confessional schools in Bosnia maintained their position relatively well against communalizing pressures. Their numbers remained on a fairly even trajectory until cultural autonomy was won in 1905 . Thus the 56 recorded in 1879 became 61 in 1891, 64 in 1900-1901 and 70 in 19056 , to rise to 123 by $1912-13$ after the winning of Serb cultural autonomy. These figures disguised considerable local shifts: from 1881 to 1890 thirty three new schools opened, twenty nine closed and three closed and reopened. ${ }^{42}$ This reflected the same kinds of difficulties as elsewhere, inadequate finance, low wages and rapid turnover of staff. There was no common syllabus till 1907 and general pension provisions only came into force in 1911. The relative stability, even if it amounted to stagnation in the face of the growth of education overall, invites comment. The morale of the Serb school movement remained intact. Indeed, Bosnia was a popular destination for young graduates of Serb teacher training colleges elsewhere. Stevo Kaluđerčić listed 44 such teachers from Vojvodina who came to Bosnia; Kaluđerčić, himself a Vojvođanin, director of the Serb higher girls' school in Sarajevo and a long-standing national 'cultural worker' in Bosnia is testimony to this morale. ${ }^{43}$ The institution of the 'church and school commune' had developed in Bosnia from Turkish times and the Ottoman millet system of local Christian selfgovernment. Wealthy merchants, the richest in Bosnia, dominated these communes, providing funds and leadership in the drive for Bosnian Serb cultural autonomy; Sarajevo commune had set up its own school fund in 1850. It is likely that the stronger position of the Bosnian Serbs, as the relative majority in a province Serbs traditionally considered theirs, made for the greater endurance of the Serbian school than in Croatia-Slavonia. On the other hand, it is worth noting some Serb views that the sums spent growing the Serb schools after the 1905 autonomy statute were a misuse of resources. The real fight, the argument went, should be on building the Serb presence in

\footnotetext{
${ }^{42}$ Calculated from annual reports to Vienna on the state of primary education in $\mathrm{ABiH}$, ZMF; Ivanišević1909, 393-99, 483-923, 789-837 and Dlustuš 1894, 103-06.

${ }^{43}$ Kaluđerčić 1939, 193-209.
}

the state secondary schools ${ }^{44}$ The Bosnian Serb teachers' journal Srpska Škola (1912-1914) gives depressing evidence on apathy among confessional teachers, and discontent at exploitation by the Serb secular intelligentsia. The Serb school issue is probably at the root of Serb blackening of Dlustuš as a Habsburg Croat minion. Dlustuš did have a low opinion of the Serb confessional schools and his insistence on Bosnian pupils' common nationality would have urked Serb nationalists. But this probably proceeded from an old-fashioned sense of south Slav unity; he appears from his writings as a warm-hearted pedagogue. ${ }^{45}$ The situations were not wholly comparable in another sense. Communalization of Serb schools in Croatia-Slavonia involved internal tensions between Serbs and Croats on religious and ethno-national lines. In Bosnia it was a contest between Serb schools and a non-Slav government. Further discussion therefore awaits the next section, on the impact of external pressures on south Slav schooling.

\section{The people's school and Austro- Hungarian government}

This section takes another traditional explanation for frustrated educational development - foreign rule: persecution and neglect. How far is this justified? There is a clear prima facie case for nationalist charges. Foreign minister Gyula Andrássy justified an Austro-Hungarian occupation of Bosnia to the great powers on the grounds that the Monarchy was 'a conservative, non-Slav state, though more than half its population was Slav. Croatian autonomy, still more Serb cultural rights in the Sremski Karlovci Patriarchate counted for little against Austro-German and Magyar hegemony. After 1875 the Hungarian government approved only one legislative proposal from the Serb National Church Congress, finally suspending its autonomy altogether in 1912. Men like Khuen and Kállay had other loyalties than to their south Slav subjects, whom

\footnotetext{
${ }^{44}$ For material on this, see Spomenica ... 1939: Sopstveni spisi, and Pitanje...1910.

${ }^{45}$ See Dlustušs long letter to Thallóczy in ABiH, ZMF, Pr BH 1282/1904, 17 May 1905. Kaluđerčić claims that Dlustuš was rebuked by Filipović for an attack on Serbs and Serb schools in 1871: Spomenica... Sopstveni spisi.
} 
both viewed sardonically as Orientals given to fantasy. ${ }^{46}$ In government eyes teachers figured prominently as purveyors of these fantasies, the Panslav dreams of official denunciation. Teachers in turn in journalism and memoirs played a leading role in fanning resentment of a vindictive anti-national regime. ${ }^{47}$

The masterful Kállay was a particular object of opposition rage. He followed a distinctive school policy, directed particularly against Serbs (Franciscan schools largely closed or were communalized in the 1880s, leaving only girls' school run by nuns in the Catholic confessional sector). Thus systematic communalization of weak Serb schools such as occurred in the Croatian Krajina and of which there were traces initially in BosniaHerzegovina was not pursued, no doubt because it conflicted with Kállay's wish for few but good schools which would then draw the population towards them. ${ }^{48}$ The fortunes of Serb schools were closely watched and when assumptions that they would wither away were not realized harassment was stepped up. ${ }^{49}$ Delays in approving the appointment of confessional teachers often left Serb schools closed for several months, in a number of cases in the 1890s (Glamoč, Ljubuški) several years; the regulations surrounding necessary certificates of political reliability became a leading issue for the opposition. Bosnian school matters were regularly followed by the Serb press outside Bosnia, state intrigues denounced and successful resistance praised. ${ }^{50}$ All in all, at least thirty one Serb confessional teachers passed over to state schools by 1899 , often because of bad relations with their commune leaders. Politically motivated transfer of teachers in government

\footnotetext{
${ }^{46}$ For Khuen on this theme, Haus, Hof- und Staatsarchiv, Politisches Archiv, XI 261: Khuen-Héderváry to Kálmán Tisza, 6 May 1887.

${ }^{47}$ See, for example, Bekić 1936 on the origins of the 1882 Herzegovinian revolt. Sarajevo confessional teachers were also heavily involved in early Serb protests against the occupation.

${ }^{48}$ Bezirkvorsteher Karl Plentajs opening of eight schools in Bijeljina district reported in 1880 probably involved communalization of existing schools.

${ }^{49}$ In 1891-2 Serb schools grew from 61 to 69, outstripping state school performance and causing alarm: $\mathrm{ABiH}, \mathrm{ZMF}$, BH 5300/1893: ZV to ZMF, 11 April 1893.

${ }^{50}$ For example, Srbobran 1887, nos 20, 32, 38, 50, 53, 54, quoted in Šušljić, Rukopis, R-390/20, pp. 136-42. This manuscript was destroyed in the burning of the Bosnian National Library in 1993.
}

schools, Serbs or Croats, was common in both Bosnia and Croatia. Izidor Kršnjavi, the able if cynical pro-regime head of the Croatian culture ministry in the early 1890 s, denied it. He had received a couple of denunciations a year, he said, but had thrown them in the waste-paper basket. ${ }^{51}$. This was disingenuous. Croatian political transfers were particularly numerous in election year 1897, and official documents show that there indeed was what the Diet opposition called špijunstvo. ${ }^{52}$ Informers were a special feature of the Kállay's regime.

Neglect was another major issue. Government secretary Kukuljevićs abandoned proposals in 1879 had called for sixty boys' and thirty girls' schools in the first year, and six Kreis school inspectors each with substantial salaries of 2,100 florins a year. ${ }^{53}$ Three years later there were only forty three schools and the post of provincial school referent, let alone Kreis inspectors, had been abolished. Only a quarter of the Bosnian educational budget for 1889 went on primary schooling in $1888,0.7$ percent of the whole and less than a twentieth of what was spent on the gendarmerie; the concentration was on a limited number of secondary and craft institutions needed to staff lower positions in the bureaucracy. ${ }^{54}$ Provincial government proposals in 1894 that the pace of school building should be raised were vetoed by Kállay. Only twenty four of the 152 schools listed in this proposal to be built in the next five years had actually materialised by 1906; further proposals for 1908-1912 did not fare much better. ${ }^{55}$ The Bosnian school administrator Dlustuš wrote privately but pointedly at this time that financial considerations remained as ever 'a negative element in the cultural progress of humanity' and particularly should not be allowed too far-reaching an influence in education. ${ }^{56}$ It was only strong criticisms of this record in the Bosnian Diet opened in 1910 that brou-

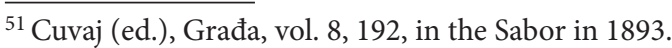

${ }^{52}$ Arhiv Hrvatske, Odjel za bogoštovlje i nastavu, Prezidijal 1897, 1-69.

${ }^{53}$ ABiH, ZMF, BH 5031/1879: Kukuljevićs draft law, 26 September 1879.

${ }^{54}$ National Achives (London), Foreign Office, 7/153: Consul Freeman to Salisbury, 11 February 1889.

${ }^{55}$ ABiH, ZMF, BH 6479/1894; ibid., Pr(ezidijal) BH 497/ 1906.

${ }^{56} \mathrm{ABiH}, \mathrm{ZMF}, \mathrm{Pr}$ BH 1282/1904: Dlustuš to Thallóczy, 17 May 1905.
} 
ght a substantial change of policy. In bills for the 1913 Diet the government committed 9,700,000 $\mathrm{K}$ investment into a building programme, including 240 rural schools over six years. ${ }^{57}$ This more expansive policy extended to teachers' material interests which previously had been given short shrift. Bosnian teachers did not receive a pension rights until 1892, and regular complaints by Bosnian and Croatian teachers about pay received little sympathy. Khuen ironised in the Sabor that they could nonetheless afford to build 'palaces' - a comment on the Teachers' House proudly opened in Zagreb in 1890. Complaints about pay continued, swelling with inflation in the 1900s. By this time, however, there was talk of the over-production of teachers, particularly women teachers, and the danger of intellectual unemployment. Lajos Thallóczy, the Joint Finance Minister's highest cultural official, counselled relying on the law of supply demand to force down teachers' pay and banning the employment of married women, which had long been a talisman of the progressive teacher movement. ${ }^{58}$ Yet Baron Cuvaj's figures indicate that the number of pupils per Croatian primary school teacher rose in these years. ${ }^{59}$ The authorities were nonetheless strongly opposed to non-official initiatives to help fill gaps in state provision. A notorious episode which loomed large in nationalist history in the mid 1900s was the Bosnian administration's requirement that students running literacy courses for peasants in their vacations should hold a teacher's certificate; it feared the prospects these gave nationalist youth for political propaganda. ${ }^{60}$

It is not surprising that native patriots should have felt their development was being held back by foreign rule. Figures collected by the Bosnian administration in 1906 showed that less was being budgeted there for cultural matters (church and school) than in neighbouring independent countries: 6.2 percent, compared to 7.3 per cent in Serbia and higher in Bulgaria and Romania.

\footnotetext{
${ }^{57} \mathrm{ABiH}, \mathrm{ZMF}, \operatorname{Pr} \mathrm{BH}, 1150$, Biliński to Franz Joseph, 15 July 1912.

${ }^{58} \mathrm{ABiH}, \mathrm{ZMF}, \mathrm{BH} 13961 / 1903$. This document's 'Votum' is unsigned but reflects Thallóczy's views expressed elsewhere. For his view that women teachers' celibacy should be considered, see his long report on Bosnian education in $\mathrm{ABiH}$, ZMF, Pr BH 1282/1904.

${ }^{59}$ Franković 1958, 249: 1903/4, one teacher for eighty-four 84 children; 1913/14, one teacher for ninety.

${ }^{60}$ See ABiH, ZMF, Pr BH 1092/1910 for a survey of this issue.
}

${ }^{61}$ However, the extent and effect of political illwill should not be exaggerated. There was nothing like the imposition of Russian as language of instruction in Tsarist Poland. Political transfer of teachers was hardly a draconian punishment, though it was not democracy. In practice, Slav activists also prioritised secondary education; the Bosnian cultural societies Prosvjeta, Napredak and Gajret were all set up (in 1902-03) to fund scholarships to expand native intelligentsias. All nineteenth-century governments economised on primary education and paid teachers poorly. Within the Monarchy Bosnian teachers received better pay than many in Croatia to attract recruits, and Khuen was probably right to point out that Hungarian teachers were even worse off than Croatian ones. The 1906 Bosnian enquiry concluded that primary school spending should be stepped up, as indeed happened in the years before 1914. Literacy figures (for 1910, Croatia 44 per cent and Bosnia 12 per cent; for 1900, Serbia: 27\%) suggest, given Bosnia had been under western-style rule less than twice as long as Serbia, that the chief drag on progress was the social backwardness of the region. Foreign rule was a problem, but less important than the objective difficulties of undeveloped peasant societies. In 1910 the proportion of the population engaged in agriculture in Croatia-Slavonia was 78.4 per cent; in Dalmatia it was higher and in Bosnia higher still. Bosnian children reared in peasant hovels arrived in school with torn shirts and inadequate clogs, physically and mentally too undeveloped to benefit properly from formal education. ${ }^{62}$ Croatian teachers also criticized incorrect speech, reflecting the prescriptive attitudes of the time in a country where regional dialects often diverged sharply from the standard language. Many commentators thought education should start later because in the long years between leaving school and reaching maturity children habitually forgot what they had learned; but it suited peasant fathers to have them back as workers as soon as possible and mothers wanted them off their hands. ${ }^{63}$ All this took a heavy toll on attendance, particularly at harvest time, in winter and

\footnotetext{
${ }^{61}$ ABiH, ZMF, Pr BH 497/1906: Bericht des Sektionsschef Ludwig von Thallóczy, 7 May 1906.

62 Školski vjesnik, 7 (1900), 561-65; ibid., 15 (1908), 839-43.

63 Školski vjesnik, 16 (1909), 18; 66-67. Bosnian Muslim teachers also favoured a later start so that Muslim children who
} 
in mountainous areas of scattered settlement, which characterized most of Bosnia. The Bosnian school administrator Dlustuš concluded that Bosnia's four year school was simply not enough to make an impact in these circumstances: Bosnia lagged far behind its neighbours (Hungary, Croatia and Dalmatia), but these with five or six years schooling and some continuity teaching were at only a 'modest' level of development. Eight years were needed, he affirmed. But building costs and popular attitudes were the problems. ${ }^{64}$ As it was, Croatian school attendance rose from around $30 \%$ to $71 \%$ of eligible children between 1850 and 1914 and in Bosnia in 1910 to about a third. Attendance in higher years of school and by girls was markedly lower. Behind such figures lay political but still more socio-economic difficulties which allowed the movement for the 'people's school' only a very qualified success. The subjective factor in the process, both the response of 'the people' to the efforts on their behalf (Dlustušs 'attitudes') and the response of educationalists to their chequered progress finally merit attention.

\section{The people's school : subjective factors}

In view of the problems facing them, religious and ethnic discord, political suspicion, material want, it is clear that the hymns to staleška svijest and the nobility of the teachers' cause in their journals were whistling to keep their spirits up. The reader is constantly struck by the gap between ideals and reality. The good teacher, said Mijat Stojanović in Napredak in 1881 must be patient, agreeable, well-intentioned, suitably strict where necessary, correct and educated in speech and endowed with a strong understanding; but he must also have physical gifts: 'an upright bearing, a noble face, a broad chest, a healthy body, a confident stride ... The dedicated teacher is already seated early in the morning at his writing table. ${ }^{35}$ In Školski vjesnik in 1909 Dlustuš listed nearly fifty aspects of people's lives, economic, cultural, associational, medical, moral, folkloric, domestic and communal, on which teachers

had to attend a reformed mekteb before the communal school would not be so much older than the others: ibid., 61-65.

${ }^{64}$ Dlustuš 1909, 1-22 (18).

${ }^{65}$ Stojanović $1881,173,189$. should record observations in the note-book they should always carry with them. ${ }^{66}$ The good teacher rejoiced at his success, even if he got no praise or recognition, wrote Klobučar in $1902 .{ }^{67}$ But ordinary teachers in letters to journals and petitions to government tell a different story. Far from living the heroic role claimed for them by the above, they complained of low pay and low status. Living in remote places, among people of different life-style, the large majority of teachers died before becoming eligible for their pension. Tuberculosis was a plague but two visits to a doctor cost a village teacher a month's wages, and the need to keep up appearances, subscribe to professional journals and associations and educate children appropriately meant marriage was extremely difficult on an average salary. ${ }^{68}$ Above all, teachers were not respected. Going to a training college was seen as the act of those who had failed to get to a Gymnasium. Dlustuš himself said that only three or four in a hundred applicants for training did it with any enthusiasm, adding that that came later. ${ }^{69}$ For many it did not. Disillusionment and apathy set in and withdrawal from teacher societies and periodical subscriptions. Teacher meetings plainly had an initial charm for some teachers and were eagerly looked forward to, providing the same sense of participating in something important which the meetings of trade unionists or Protestant revivalists could have in other societies. Problems of ineffective organization, ill-defined agendas and growing awareness of limited influence often led to decline, however, and the moribund state described as 'mrtvilo'. As to the professional literature to be read in the evenings in the idealized view, much of it seems drily repetitive or else implausibly ambitious for men of humble background and education. The country was 'flooded' with methodological journals whose content was 'always the same, just a little different!' commented one experienced teacher ironically. ${ }^{70}$

\footnotetext{
${ }^{66}$ Dlustuš 1909, 8-9.

${ }^{67}$ Klobučar 1902, 57.

${ }^{68}$ Napredak, 24 (1883), 176-68: 'Seoski i gradski učitelji' (doctors); ibid., 29 (1888), 187-88: 'Pomor megju hrvatskim učiteljstvom' (pensions); and 100-106: 'Koliko da je plaća pučkoga učitelja u Hrvatskoj i Slavoniji' (budget); There is a great deal of similar material.

${ }^{69}$ Dlustuš 1873, 153.

${ }^{70}$ Ignotus 1906, 131.
} 
At the root of teacher disillusionment was the fact that the peasant majority did not understand the idea of schooling for citizenship and improved skills. One reason teachers wanted better salaries, it seems, was that this would increase their status in the eyes of people who saw success, teachers believed, only in material terms. That peasants preferred everything to a book was a common refrain. ${ }^{71}$ For them school was only about becoming a 'gospodin', so irrelevant to them and their children. Indeed, it had been easier to become a gospodin in the old-fashioned schools, with a little literacy and German, complained former Military Frontier peasants in 1889. Klobučar, who reported this, reacted by saying peasants must give up the idea of becoming gentlemen (as any clerk who did not live by his hands appeared to them); now this required a few years of secondary schooling and that needed money they did not have. Times were hard, he added, and the people's school could not solve the economic problem. But it was the only way forward, the way which led to the ennoblement of the heart and the strengthening of the humane idea. This was an interesting response of a longstanding pedagogue to the mounting difficulties of his vision. Recognising that schooling alone would not bring about the new order the original idealism of the teacher movement had assumed, Klobučar did not lapse into apathy but reasserted the goal for a more distant future. Thus he opposed giving the communal school an agricultural orientation, but stuck to his core belief in the awakening of popular consciousness and selfhood. ${ }^{72}$ Not only in material matters was the practical efficacy of general education less evident than had been thought. In this 'confusing time', as Ljudevit Dvorniković told the 1887 annual general meeting of the League of Croatian Teacher Associations, some people were saying that education and civilisation were weakening morality, not strengthening it. ${ }^{73}$ A Napredak editorial in 1902 noted that crime figures were on the rise. ${ }^{74}$ An 'age of change' was as common a phrase as in the 1860s but it no longer evoked such positive associations. The earlier period had stressed the

\footnotetext{
${ }^{71}$ Dlustuš 1909, 27.

${ }^{72}$ Klobučar 1889, 161-68.

${ }^{73}$ Dvorniković 1887,419

${ }^{74}$ Napredak, 43 (1902), 449: 'Ćudorednost i pučka prosvjeta', 419.
}

role of competition too, but this had been viewed through an aspirational prism and not the bleaker reality which Klobučar wanted 'to beat into' peasants' heads. $^{75}$

How did teachers face the changing climate? Many if not most of them seem to have met it with a degree of apathy and resentment. They were the bottom rung of a small intelligentsia in an overwhelmingly peasant society. Much of their resentment was directed at parents for their indifference and hostility, ignorance of hygiene and the poor condition of the children they delivered to the schools. It could extend to the 'prickly little savages' themselves. Several writers proposed measures for the punishment of parents who having enrolled their children failed to ensure they attended; one suggested medical inspections for all those intending marriage. ${ }^{76}$ This consistent vein of teacher criticism of the communities in which they worked reflected frustration at the abiding sense that the school was not popular, indeed was being given some of the blame for people's difficulties at a time of mounting socioeconomic stress in the south Slav countryside.

Leading teachers' role obliged them to take less negative stances. Dvorniković called on teachers to recognize that both they and parents shared the blame for the negative atmosphere surrounding the school; without this the situation would not change. ${ }^{77}$ Klobučar's position was less conciliatory; as suggested above it was a dogged repetition of traditional themes of education's ennobling mission. In Ljuboje Dlustuš, the educational bureaucrat, we see something less abstract, a true believer also but emphasising the bond of teacher and pupil in an atmosphere of unity and emotional sollicitude. Meeting a peasant who declined to send his able son to the Gymnasium because he wanted help from him to calculate his ingoings, outgoings and savings more exactly, Dlustuš says he could have hugged him. ${ }^{78}$ The peasant's view that schooling's purpo-

\footnotetext{
${ }^{75}$ Phrase like 'marljivost, radinost i štednja naroda' (Napre$d a k, 10,1869,247)$ and references to the English self-help utilitarian Samuel Smiles show the influence of bourgeois thought alongside the romantic, idealistic currents of the earlier period. For Klobučar, see Napredak 30 (1889), 163.

76 Školski vjesnik 7 (1900), 561-65; (inspections); ibid., 15 (1908), 31-35; ibid., 15 (1908), 839-43. For the 'prickly little savages', see Napredak, 21 (1880), 155.

${ }^{77}$ Dvorniković $1887,419$.

${ }^{78}$ Dlustuš 1909, 19.
} 
se should be to make farmers better farmers was the positive lesson he wanted all people to have. The Muslim educationalist Hamid Mulić had the same practical vision when he wrote of a father who did not send his son to school, seen only as making 'gentlemen': 'The poor man doesn't know that fine craftsmanship leads a people to happiness and prosperity. ${ }^{\text {'79 }}$ In Dlustušs case at the end of his career the perspective - as it had probably always been for someone maturing in early constitutional Croatia - was of a society where people could fulfill their duties and exercise their rights in participating in their country's legislature, far as Bosnia's 'cultural circumstances' were from enabling it. He looked to the impending Diet to take up the problems of resources and popular misunderstanding faced by the schools. ${ }^{80}$ This was the life-time public servant's characteristic mix of ideal and stoicism. There was another type of figure, the life-time radical, like the Croat teacher-writer of Slovene origin, Davorin Trstenjak (1848-1921), whose later writings reiterated the unswerving faith of his rationalist, anti-clerical youth: 'there you have on the one side the fruits of clerical darkness, and on the other the gifts of free knowledge, free thought and the free school - of healthy reason!'81 A Trstenjak could turn even the hardhips of the teacher's life to affirmation: did not pain and suffering bring forth joy and beauty, as Poland's fate had created great literature, Croatia’s 'Čengić-aga', mothers' labour pains their children and writers' creative anguish their masterpieces! ${ }^{82}$

Trstenjak's uncomplicated beliefs point to another aspect of the primary school movement between 1850 and 1914. Its leaders like those they led were of humble origin. Not one of them had gone to university; though some completed Gymnasium, many, like Trstenjak, did not, often for financial reasons; some went straight into teaching or training college without other secondary school experience. None were of conventional bourgeois background. Diesterweg and Dittes also shared this background. The primary school teachers of nineteenth-century

\footnotetext{
79 Školski vjesnik, 16 (1909), 783.

${ }^{80}$ Dlustuš 1909, 19.

${ }^{81}$ Trstenjak, 'O modernoj školi i modernim nazorima o prirodi i čovjeku', in Franković 1978, 194-99 (195). First published in 1909.

${ }^{82}$ Trstenjak 1902, 44-45.
}

Europe offer arguably the most striking example of the rise of the common man in a period of unparalleled social change. Effectively, a new profession was created, with its own literature, journals and institutions. Though the literature is impressive, at times the unproblematic acceptance of a naturalistic rationalism marks its humble origins. The 'derivative' nature of much Balkan culture, to use Filipovićs word, can contribute to the same impression, as in Učitelj's assurance that Darwin's struggle for existence did not mean 'a brutal struggle between crude forces' but goaldirected effort leading to ever greater perfection and humanity - though similar simplifications marked radical movements in more developed countries too. ${ }^{83}$ In the strongly status-conscious pre-1914 world primary school teachers were doomed to remain a subaltern social group. This is the bitterness in Filipovićs reference in Beckke pedagoške slike to the Croatian teacher as 'the most under privileged creature in the world. ${ }^{84}$ In the Balkans this marked their relations with their own elites, non-dominant as these were visà-vis outsiders. This can be seen in Serb teachers' resentment at being used as foot-soldiers in the battle against communalization of confessional schools in the Sremski Karlovci Patriarchate, and in the well-known tensions between them and the merchant leadership of the Bosnian Serb movement for cultural autonomy. It can be seen, too, in Zora's assertions to Dalmatian provincial leaders that it was independent (of government) and working only for the interests of teachers. Zora suspected politicians of exploiting controversy over rural one-class schools to ensure a backward hinterland's subservience to the coastal towns. ${ }^{85}$ An editorial on clergy and teachers in the elite organ of Dalmatian national liberalism, Narodni list, made the balance of forces perfectly plain. In the undesirable event of conflict between these two bodies, social and national interests spoke unequivocally in favour of the clergy, as preachers to the pious masses of submission to authority, and as the greatest historical defenders of nationality. ${ }^{86}$ The way the case of the people's school drew out the bare bones of Balkan soci-

\footnotetext{
$\overline{{ }^{83} \text { Učitelj, } 1 \text { (1874), } 83}$.

${ }^{84}$ Filipović 1870, 20.

${ }^{85}$ Zora, 1 (1884), 1-5; 158-60, 166-68; 2 (1885), 98-99.

${ }^{86}$ Narodni list 28 (1889), nos 27-28: 'Svećenstvo i učiteljstvo u Dalmaciji'.
} 
al structure and its relation with other defining characteristics of Balkan society, religion and nationality could hardly be better illustrated than here.

In the pre-1914 generation, the first university educated figures with pedagogical associations began to appear. Mostly, they took their doctorates abroad in German-speaking institutions, like Jure Turić, Pero Radosavljević and the Bosnian Muslim Salih Kazazović. But Albert Bazala preceded them in 1900. with a doctorate in Zagreb university where a pedagogical seminar have been founded in 1894 . The starting point of Turićs doctorate was Herbart's metaphysics; Radosavljevićs second doctorate, from $\mathrm{New}$ York, was in pedagogy. All these men moved in the direction of psychology or philosophy. These themes were taken up in pedagogical periodicals by teacher training college teachers like Ljudevit Dvorniković or Dr Gjuro Bugarski. Several of these men were drawn to aspects of the educational movement's original idealism. Bazala first suggested the idea of the Zagreb University launched in 1912 for adult education. He like most of the above was Yugoslav-orientated. But on the whole the prewar decades saw a change of mood. In this 'age of change', wrote a reviewer, the climate did not permit clear-cut educational principles. Every opinion was conflicted; pedagogy reflected the same agitation as has dominated the whole general culture of our time ${ }^{87}$ The shift from the optimism of the early popular school movement was part of wider social doubts about mid-nineteenth century liberal progress. In place of earlier assumptions about the reconciliation of interests came a less altruistic view. 'Society recognizes the freedom of the individual only inso far as, using this freedom, the individual benefits society. The tension was to be resolved by emphasis on social solidarity and (implicitly) nationalism. ${ }^{88}$ There was another possible resolution: it was being prepared by the educational philosophy of the Radić brothers. This had several points in common with the older movement: its idealism, in which ideas of enlightenment (prosvjeta) were bound up with ideas of the nation; the concern for pupils as human beings with

\footnotetext{
${ }^{87}$ Napredak, 52 (1911), 89.

${ }^{88}$ Ljudevit Krajačić, 'Škola kao socijalno-obrazovna i odgojna institucija, ibid., 54 (1913), 193-204 (193).
}

their own inner purpose; the desire to reconcile the intelligentsia and the people with the people's school. But the attitude to religion was much warmer than with Napredak and the brothers' Croatian patriotism lacked the Yugoslav gloss of the early liberal age. The people's school movement in the progressivist sense of a Filipović was a thing of the past.

This movement's distinctive character lay in its timing. It became a force when the rationalist spirit of Enlightenment broadened beyond the ranks of intellectuals into the liberal current of the nineteenth century with its challenge to traditional political and social structures. The challenge was mediated from western and central Europe to the less developed south Slav lands of the Habsburg monarchy, in the case of education chiefly via German Protestant theories of the Volksschule under the control of lay teachers, free from government or clerical tutelage. How fully these ideas were adopted varied, but a strengthened sense of primary school teaching as a profession came into being, along with a claimed association with advances in modern knowledge and 'progress'. There were striking similarities in forms of organization and considerable inter-regional linkages, notably between Bosnia and Croatian and Croatian/Hungarian Serb teachers. If Croatia saw the people's school movement emerge most clearly in the circles around the journal Napredak, Bosnia was a leading forum for its testing, because it posed most sharply the question of which 'people', which educational pioneers had answered with liberal optimism in terms of a hazy fraternal Yugoslavism. The long regimes of Khuen-Héderváry and Kállay following the Bosnian occupation helped consolidate frustration. But the issue was not just Bosnia but the religious and ethnic complexities and social backwardness of the region, and the Balkans, as a whole. Nor was this only a Balkan matter. An aspect of European liberal optimism, exaggerated in Balkan reception of outside ideas, was to assume that religious and ethnic identities could be relatively quickly reconciled by appeals to rational civism and economic development. The decline of liberal optimism in the decades before 1914 was a European-wide phenomenon.

Yet this presentation should not end only on a negative note. The structures established by educational pioneers had a firm foundati- 
on. Croatian teachers organized by their Savez were able to sustain a strike in 1911 which raised wages substantially, if not as much as they would have wished. The tradition of interconfessional education was implanted in Bosnia. Many features of the progressive movement were taken over by new forms of teacher activism, as by the Radić brothers or by socialists. In an autobiography printed in Školski vjesnik (1906-8) the pseudonymous Ignotus vividly describes the enthusiasm of his youthful calling to be a teacher, then the disillusion when he sees the indifference of peasants to what he has to offer and the indifference of his fellow teachers who have given up. But he concludes that his early dreams were not wrong. 'The shattering of illusions is not the annihilation of ideals, but their establishment on a more realistic basis. ... My school immediately destroyed my illusions about the people's wish for cultural enlightenment, but did not in the least shake my idealist conception of the teacher's calling. ${ }^{89}$ These moving words have a relevance beyond the sphere of the movement I have tried to describe.

\section{Rezime \\ Osnovno obrazovanje u južnoslavenskim zemljama Habsburške monarhije $\mathrm{u}$ doba dualizma. Ideal i stvarnost}

Osnovno obrazovanje bilo je važno pitanje u balkanskim zemaljama tokom društvenih i nacionalnih buđenja u devetnaestom stoljeću. Dok je razvoj školskog sistema sa strukturiranim nastavnim planom i programom, u kojem je služilo kvalificirano, fakultetski obrazovano nastavno osoblje oba spola, dobro poznat, njegove ideološke osnove možda zaslužuju više pažnje. Ova studija uzima za polazište najradikalnije krilo pokreta, (nipošto homogenu) grupu oko hrvatskog obrazovnog časopisa Napredak (1859), koji se pod djelomičnim utjecajem njemačke protestantske pedagogije zalagao za nekonfesionalne škole oslobođene od države ili klerikalnog tutorstva, kao i

\footnotetext{
89 'Ignotus' 1907, 30. These memoirs were published in
} many installments between 1906 and 1909. za jugoslavensko bratstvo, ako su bili implicitno po hrvatskom ukusu. Učitelji iz Hrvatske imali su značajnu ulogu u razvoju osnovnog obrazovanja u Bosni, iako se zaključno usvajanje principa nekonfesionalnih škola više duguje državnoj brizi za suprotstavljanje utjecaju bosanskih Srba - čije su konfesionalne škole razvijane zahvaljujujući imigranatima iz Monarhije - kao i za pružanje okvira za akulturaciju bosanskih Muslimana. Idealizam obrazovnog pokreta potopila su tri glavna faktora, pogoršana službenom sumnjom: vjerska opozicija u katoličkim, pravoslavnim i muslimanskim taborima; povezane etno-nacionalne razlike u posljednja dva slučaja $i$, konačno, manjak resursa u još uvijek nerazvijenim društvima. Proračun za obrazovanje trošen je isuviše nesrazmjerno na školovanje nakon osnovnog, odražavajući sklonost elitnim i instrumentalnim financiranjima "staleških" linija, a neobrazovanju "covjeka" liberalnih ideja. Pored objektivnih teškoća postojao je problem nezadovoljstva nastavnika u vezi s jazom između ideala i stvarnosti, i njihovim niskim statusom među uglavnom ravnodušnim, ako ne i neprijateljski nastrojenim stanovništvom. Sudbina osnovnog obrazovanja postala je tako symbol poteškoća s kojima se balkansko društvo susretalo u procesu "modernizacije".

\section{Bibliography}

Alter, P. J. 1974, Habsburg School Reform among the Orthodox Minorities, 1770-1780, Slavic Review 33, 1974.

Bekić, D. St. 1936, Borba srpsko-pravoslavnog Opštestva u Mostaru protiv austro-bosanske uprave 1880-1882 godine, Sarajevo 1936.

Bogićević, V. 1965, Istorija razvitka osnovnih škola u Bosni i Hercegovini od 1463-1918, Sarajevo 1965.

Cuvaj, A. (Ed.) 1913, Građa za povijest školstva kraljevina Hrvatske i Slavonije od najstarijih vremena do danas, vol. 8, Zagreb 1913.

Ćurić, H. 1983, Muslimansko školstvo u Bosni i Hercegovini 1800-1918, Sarajevo 1983.

Deželić, V. 1929, Kardinal Haulik, nadbiskup zagrebački 1788-1869, Zagreb 1929.

Dlustuš, Lj. 1894, Školske prilike u Bosni i Hercegovini, Školski vjesnik 1, 1894.

Dlustuš, $L j$. 1909, Promjene u organizaciji školstva u Bosni i Hercegovini, Školski vjesnik 16, 1909, 1-22 (18).

Dvorniković, $L j .1887$, Vrši li današnja pučka škola svoju uzgojnu zadaću, Napredak 28, 1887.

Filipović, I. 1870, Bečke pedagoške slike, Zagreb 1870. 
Filipović, I. 1879, Reakcija proti školstvu, Zagreb 1879. Franković, D. (Ed.) 1958, Povijest školstva i prosvjete u Hrvatskoj, Zagreb 1958.

Franković, D. (Ed.) 1971, Sto godina rada Hrvatskog pedagoško-književnog zbora i učiteljstva 18711971, Zagreb 1971.

Franković, D. 1978, Davorin Trstenjak: borac za narodnu školu, Zagreb 1978, 194-99 (195). First published in 1909.

Ignotus, 1906, Zapisi iz života jednog učitelja, Školski vjesnik 13, 1906.

Ivanišević, I. F. 1909, Srpsko-pravoslavno školstvo u Bosni i Hercegovini, Školski vjesnik 16, 1909.

Kaluđerčić, S. 1939, Srbi i Srpkinje iz Vojvodine učitelji i učiteljice u Bosni i Hercegovini, Glasnik istorijskog društva u Novom Sadu 36, 1939.

Kasumović, I. 1999, Školstvo i obrazovanje u bosanskom ejaletu za vrijeme osmanske uprave, Mostar 1999.

Kirilović, D. 1935, Pomađarivanje u bivšoj Ugarskoj, Novi Sad 1935.

Kirilović, D. 1953, Učitelj. Prvi srpski socialistički časopis, Zbornik Matice Srpske za književnost i jezik $1,1953$.

Klobučar, D. 1889, Narod i pučka škola. Napredak 30, 1889.

Klobučar, J. 1902, Pučki učitelji spram svoga poziva i staleža, Napredak 43, 1902.

Krajačić, Lj. 1913, Školska socijalno-obrazovna i odgojna institucija, Napredak 54, 1913, 193-204 (193).

Krestić, V. 1997, History of the Serbs in Croatia-Slavonia 1848-1914, Belgrade 1997.

Krestić, V. 1997, History of the Serbs in Croatia and Slavonia 1848-1914, Belgrade 1997.

Mulabdić, E. 1898, Zeleno busenje, Sarajevo 1898.

Mustafić, I. (Ed.) 2008, Hamdija Mulić. Pedagog, reformator, književnik, vol. 2, Sarajevo 2008.
Perić, I. 1974, Borba za ponarodjenje dalmatinskog školstva, Zagreb 1974.

Okey, R. 2007, Taming Balkan Nationalism. The Habsburg 'Civilizing Mission' in Bosnia, 18781914, Oxford 2007.

Papić, M. 1972, Školstvo u Bosni i Hercegovini pod austrougarskom okupacijom 1878-1918, Sarajevo 1972.

Pitanje o uređenju srpskih škola u Bosni i Hercegovini, Sarajevo 1910.

Slijepčević, P. (ed.) 1929, Napor Bosne i Hercegovine za oslobođenje i ujedinjenje, Sarajevo 1929.

Spomenica o pedesetogodišnjici rada Steva Kaluderčića, Sarajevo 1939.

Stih, P. / Simoniti, V. / Vodopivec, P. 2008, Slowenische Geschichte, Graz 2008.

Stojanović, M. 1881, Iskustvo, stvoreno na polju uzgoja i obuke na pučkoj školi, Napredak 22, 1881.

Šetić, M. 2010. Staleška društva i časopis hrvatskog učiteljstva u Istri 1897-1914, Zagreb 2010.

Šidak, J. 1981, Jedno stoljeće u razvoju školstva u hrvatskim zemljama od 1773. do 1874, In: Ibid., Kroz pet stoljeća hrvatske povijesti, Zagreb 1981.

Trstenjak, D. 1902, Bol u uzgoju, Napredak 43, 1902, 44-45.

\section{Educational periodicals}

Hrvatski učitelj (Zagreb)

Napredak (Zagreb)

Nova škola (Zemun, Pančevo)

Srpska škola (Sarajevo)

Srpski list (Sombor

Srpski vjesnik (Sarajevo)

Učitelj (Zemun)

Zora (Zadar) 